\title{
TRADITIONAL TREE AND SHRUB FODDERS FOR LIVESTOCK FARMING IN SRI LANKA
}

\author{
GGC Premalal and S Thavarajah \\ Veterinary Research Institute, Peradeniya
}

A vast array of natural trees and shrubs are traditionally being used by livestock farmers determining the usefulness of ther through their experience are traditionally using shrubs. These plants may be represented in writings over thousands years ago as fodder trees in SriLankan traditional livestock farmin $z$ systems. These range from short structure shrubs through large trees which can grow to a height of $30 \mathrm{~m}$. Botanically they come under several plant families and basically categorizes. as leguminous and non leguminous tree fodders and both categories are equally Important as forages.

Premier reviews of the natural fodder trees and shrubs have been carried out in Sri Lanka by several investigators under several institutions. Those studies were mainly composed to regional surveys, laboratory analysis on the composition and adverse factors and simple feeding experiments.

Studies revealed that the most of tee and shrub leaves are rich in $\mathrm{CP}, \mathrm{Ca}, \mathrm{Mg}$, and average in $\mathrm{P}$ and $\mathrm{S}$, low in $\mathrm{Na}$ and trace in $\mathrm{Cu}$ and $\mathrm{Zn}$. The average Crude Protein (CP), Neutral Detergent Fiber (NDF), Acid Detergent Fiber (ACF), Lignin, Cellulose and Total ash vary from 9.0 to $28.1 \%, 33.3$ to $54.0 \%, 18.37$ to $50,08 \%, 4.7$ to $22.0 \%, 11.5$ to 24.8 and 4.6 to 14.7 respectively. There is a high variation in DCF $(5.5$ to $19.8 \%$ ) and TDN (36.3 to $83.4 \%)$. In most of the species, In-vitro Organic matter Digestibility (IVOMD) value is between 45 to $55 \%$ while few species show a value more than $55 \%$ and less than $45 \%$. In a nitrogen balance study, all the tree fodder tested was able to maintain a positive nitrogen balance. Some natural tree fodder contains anti quality substances. Tannins are most popular substances, which occur in some tree leaves. Farmers currently overcome this problem by feeding mixtures of fodders, feeding in later stagers that tannins are low in content and vilting or sun drying.

Little effort had been made to study and obtain information including production and consumption under the natural habitats and their feeding limitations. Therefore increased attention needs to given those as a team approach with all relevant institution. 